\title{
OPERATIONAL TESTS RESULTS OF THE NAVAL GAS TURBINES OPERATED BY THE POLISH NAVY
}

\section{Bogdan Pojawa}

Polish Naval Academy, Faculty of Mechanical and Electrical Engineering, Śmidowicza 69 Str., 81-127 Gdynia, Poland; e-mail: b.pojawa@amw.gdynia.pl

\begin{abstract}
This article is a continuation to the theme of the article Operational diagnostics synthesis of the naval gas turbines operated by the Polish Navy published in SJ of PNA No. 1/2017. This article presents examples of results of energy research carried out by the Polish Naval Academy in the years 1985-2016, for the purpose of operational diagnostics of this type of engine, operated by the Polish Navy. The research conducted since 1985 covered four types of naval gas turbines (DE 59, DR 76, DR 77 and LM 2500), with a total of 24 engines. Currently in operation there are four LM 2500 type engines. In the near future, another LM 2500 engine will commence operations, along with a project $661 \mathrm{M}$ patrol ship. The energy research covers the engine start-up process, their operation in idle mode and within the whole range of load variations, as well as the process of engine stopping. The article presents examples of characteristics specific to the above processes, determined based on the results of studies of individual types of engines. Currently ongoing studies allow for constructing strategies for naval gas turbines, operated in the Polish Navy, according to technical condition.
\end{abstract}

Key words:

technical diagnostics, naval gas turbine, technical condition, LM 2500 engine.

Research article

(C) 2018 Bogdan Pojawa This is an open access article licensed under the Creative Commons Attribution-NonCommercial-NoDerivatives 4.0 license (http://creativecommons.org/licenses/by-nc-nd/4.0/) 


\section{INTRODUCTION}

Current exploitation systems mostly utilize strategies based on technical condition and overall operating costs. Decisions regarding exploitation in such systems require ongoing assessment of the technical condition of an object in use. Therefore, questions whether an object is functioning properly and what is the forecast for its further operational span are constantly valid. In cases of damage it is necessary to be able to locate it, and to identify the cause. For this purpose, systematic exploitation diagnostics are applied, including energy research [1-4, 13, 26].

Because of the large amount of material, the organization of energy research of naval gas turbines in the Polish Navy was presented in the article Operational diagnostics synthesis of the naval gas turbines operated by the Polish Navy. That article presented the purpose and methodology of the research, which was to identify the object of research and test equipment used for research. In this article, which is a continuation of this theme, was presented examples of the results of these tests. These are mainly characteristics of different types of engines, determined based on the results of research. With the formulated measurement results at our disposal, it is possible to determine the characteristics of engines and diagnostic symptoms specified by individual methods of diagnosis. In order to facilitate a comparison of characteristics of the engines tested, and relate them to different atmospheric conditions, the measurement results are reduced to so-called normalized conditions (standard reference state). Based on compilation of the results of measurements, it is also possible to verify the indications of the ship control and measurement system and determine the scope of measurement errors.

\section{TEST RESULTS}

\section{Tests of engine start-up and stopping and operation in idle mode}

The start-up is an undetermined (transition) process, consisting of a series of dynamic thermal-gaseous processes running simultaneously in all turbine engine fluid-flow machines, aimed at transferring the engine from the idle state to the idle running. In other words, the start-up is the transition from the rotary rim resting state to idle speed. One of the most important requirements for turbine engine starting systems is the automatic, reliable and trouble-free start-up in all weather 
conditions $[4,5,7,8,20,25]$. Start-up characteristics depend on corresponding adjustments made in the relevant engine and on its technical condition. Therefore, they are individual for every engine within an engine group of a specific type. Due to the above, periodical control and regulation of automatic engine start-up is a necessity in the process of exploitation of naval gas turbines. Statistical analysis of the start-up characteristics also showed that the start-up process can be a valuable source of diagnostic information, enabling an assessment of the technical condition of the engine, in particular with regards to bearings, the flow tract and fuel equipment $[4,8,11$, $12,20,25]$. For this reason, the energy research encompasses start-up and stop (coasting) tests of the engine and the idle running.

Based on the characteristics of the starting and stopping processes of the engine, conclusions may be drawn about correct functioning of the automatic engine start control system, including $[8,11,12,15,25]$ :

- evaluation of various stages of start-up and correct operation of equipment and installations involved in the start-up process;

- observe the correctness of operation of fuel equipment;

- verify the achievement of required values of the start control parameters in a determined time;

- observe the correctness of the technical condition of the engine bearings;

- carry out the necessary regulations in this regard.

Based on the engine operating parameters recorded in idle running, conclusions may be drawn about the correctness of engine adjustment, as well as the correctness of operation of the fuel equipment. Analysis of the research results is carried out by comparing the measured parameter values with the control parameter values, contained in the operational documentation of the tested engine $[8,11$, $12,15,25]$.

Examples of starting and stopping (coasting) characteristics of an engine, recorded during the energy research of naval gas turbines operated in the Polish Navy, are presented in figures 1-6. For the purposes of diagnostic inference, the graphs display the waveforms of the relative values of start-up control parameters, allowing their combination on a single graph. Designations of individual control parameters are in accordance with the engine operating parameters contained in tables 3 and 4 , set out in the article Operational diagnostics synthesis of the naval gas turbines operated by the Polish Navy. 


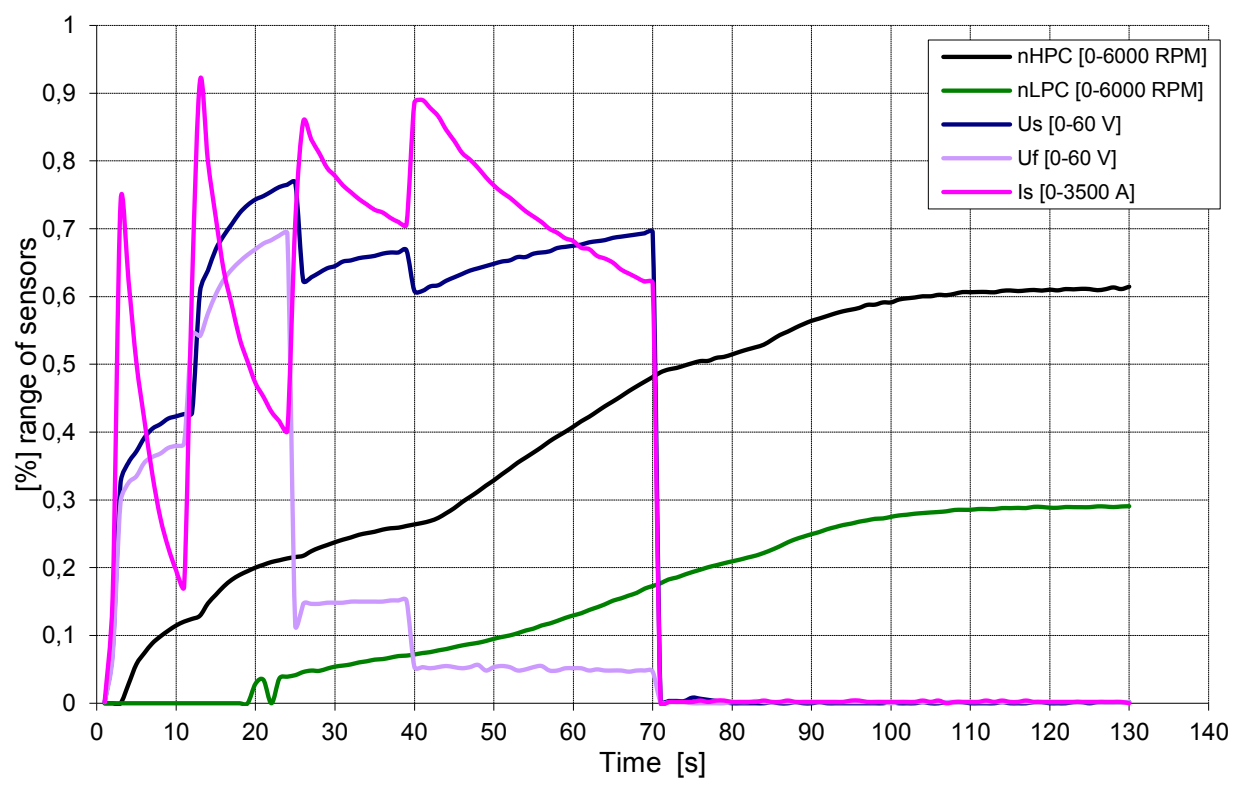

Fig. 1. Course of the relative values of control parameters for start-up of a naval gas turbine DE 59 [own study]

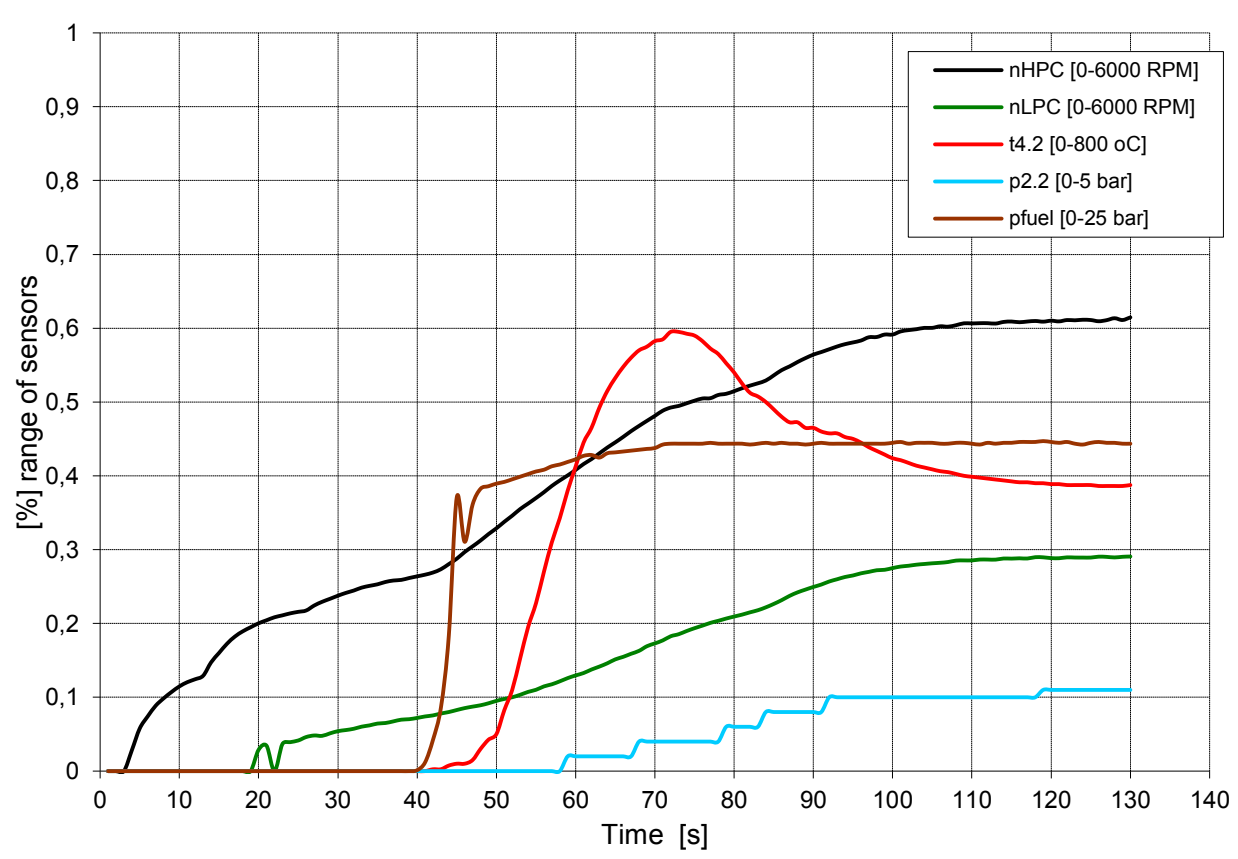

Fig. 2. Course of the relative values of control parameters for start-up of a naval gas turbine DE 59 [own study] 


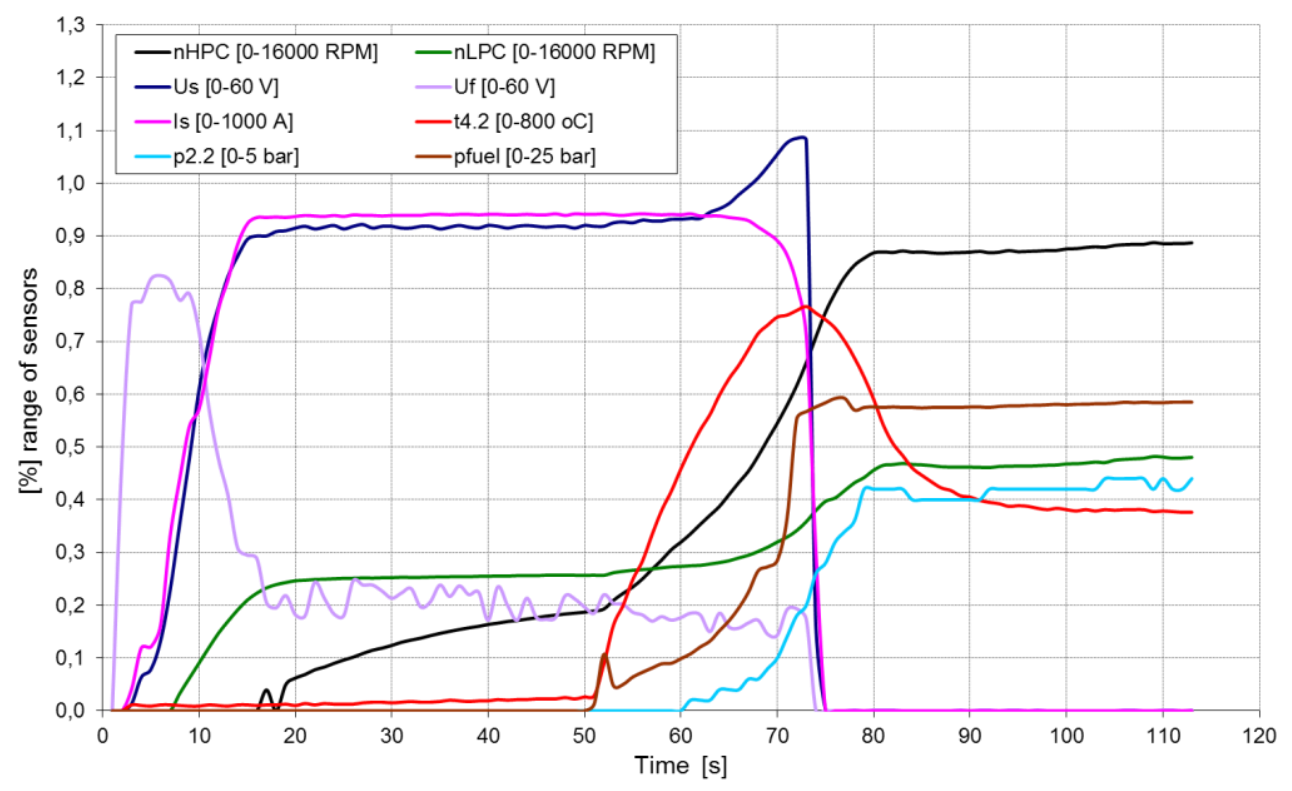

Fig. 3. Course of the relative values of control parameters for start-up of a naval gas turbine DR 76 [own study]

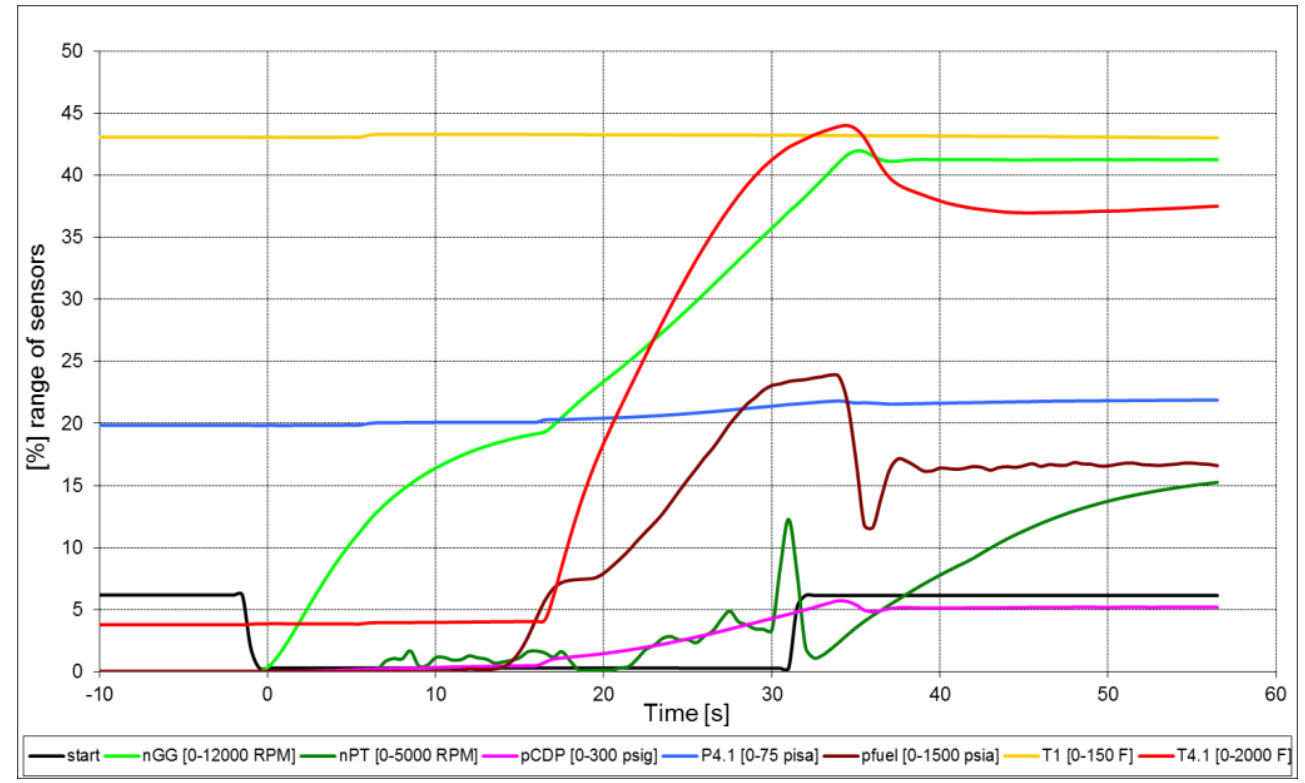

Fig. 4. Course of the relative values of control parameters for start-up of a naval gas turbine LM 2500 [own study] 


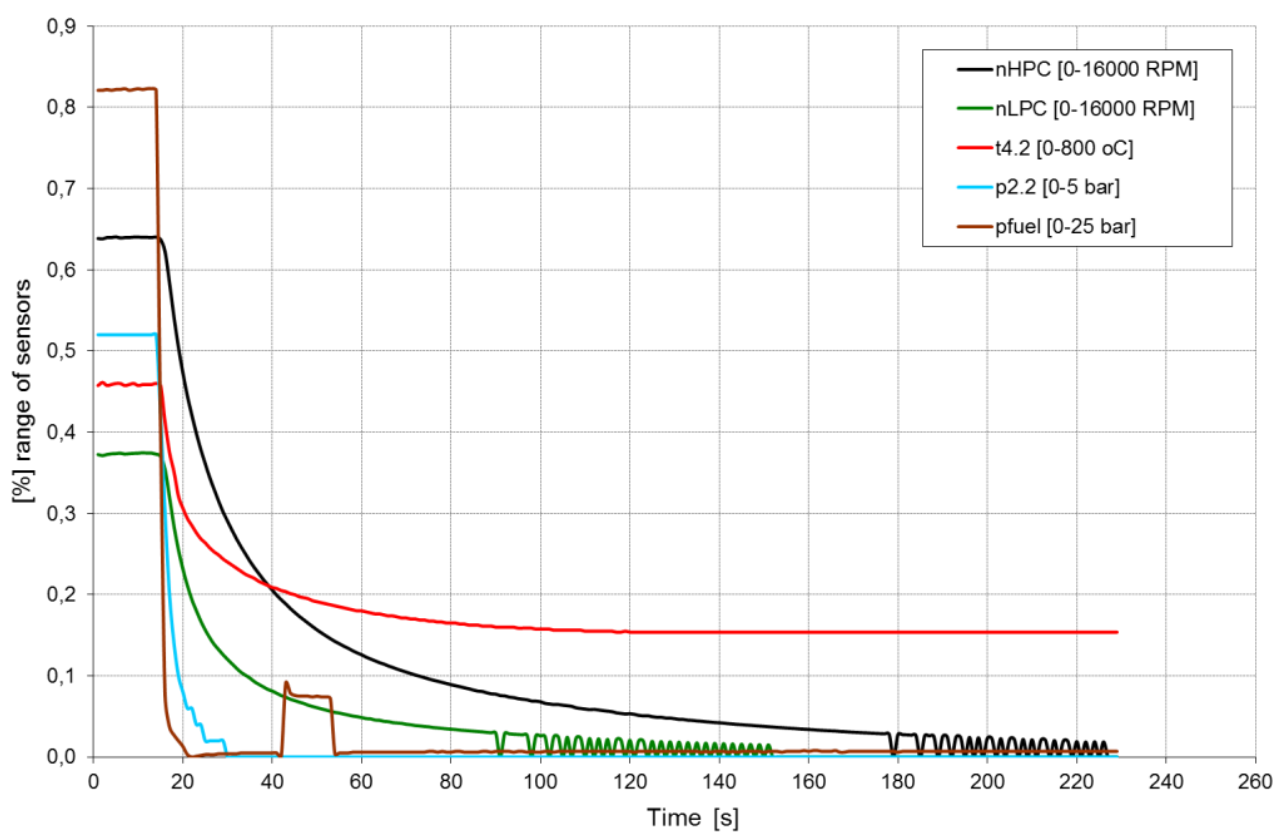

Fig. 5. Course of the relative values of control parameters for the stopping (coasting) of a naval gas turbine DR 77 [own study]

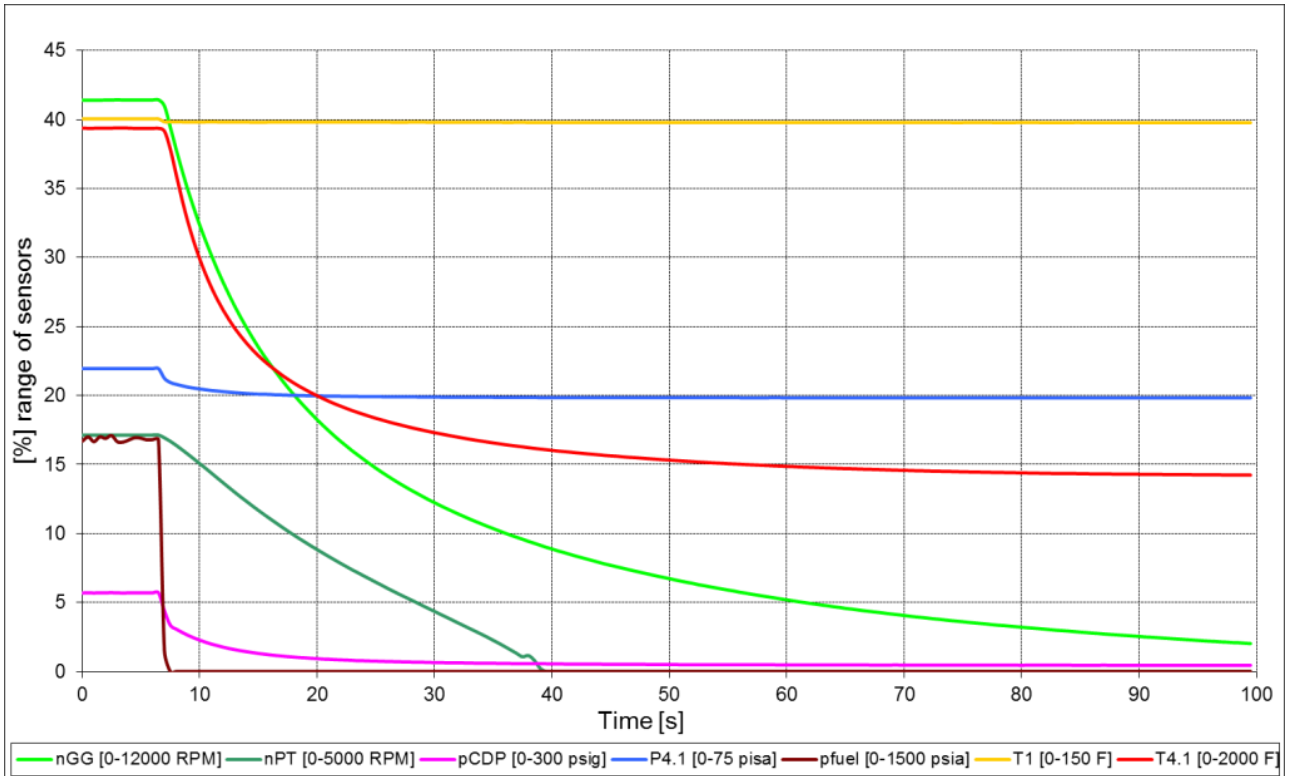

Fig. 6. Course of the relative values of control parameters for the stopping (coasting) of a naval gas turbine LM 2500 [own study] 


\section{Engine tests at sea}

The process of operation of marine propulsion systems, including propulsion engines, requires the knowledge of their possible performances, depending on their load, resulting from the speed of the ship. Each engine load corresponds to set values of parameters of its operation. Relations between basic values defining the performance of an engine cooperating with a specific receiver of energy, as well as the state parameters of the working medium, with the engine load (within the whole range of variation of its load), are shown in the characteristics of the engine. Therefore, the exploitation process requires periodical engine energy tests, to confirm the stability of these characteristics. Changes in these characteristics during exploitation of tested engines is often used for diagnostic inference, aimed at determining their technical condition $[4,6,17-19,21,22]$.

The characteristics of naval gas turbines are a result of cooperation of fluid-flow machines - the main elements of a turbine engine. These include: a compressor, a combustion chamber and a turbine. In addition, the naval gas turbine includes a free turbine, which is not mechanically coupled to the gas generator, only thermogaseous-dynamically. The energy state of an engine (gas generator) is dependent on the value of the energy performance parameters, dependent on the position of the engine control (fuel flow) lever, and directly influencing the engine power (exhaust gas enthalpy flow). In the case of a two-rotor naval gas turbine, such parameter is the rotational speed of the gas generator rotor; in case of a three-rotor naval gas turbine (with a separate power turbine and two-rotor gas generator) it is mostly the rotational speed of the high-pressure rotor. The basic energy parameters characterizing the operation of any naval gas turbine are: the effective (useful) power, torque, rotational speed of the rotors and the engine-specific fuel consumption. These parameters, depending on the engine energy state, may assume the following values: maximum, nominal, operational and minimum. In addition, we can distinguish other additional parameters characterizing an engine. In the case of naval gas turbines, these parameters include $[18,19]$ :

- the temperature and the absolute pressure of the working medium in the characteristic sections corresponding to the nodal points of implementation of the thermodynamic cycle of the engine;

- mass streams of air, fuel and exhaust;

- compressor pressure ratio. 
During the operation of naval gas turbines, the following energy states may be distinguished $[18,19]$ :

- e st a blis h ed in the extent from minimum capacity (commonly called 'idling'), to the maximum capacity, including distinctly: maximum, nominal (calculated), partial power (operating), minimum power;

- transi e n t (temporary) which include: the processes of starting and stopping the engine and acceleration and deceleration.

The characteristics of the engine are determined by its manufacturer, at designated engine test-bench stations. The characteristics of naval gas turbines set on a test-bench station may, in varying degrees, differ from those which occur in engine room conditions. The main-impact factors are air intake ducts, exhaust ducts, types of energy receiver and fuel types. Therefore, it is recommended to set the engine characteristics in marine conditions. Such tests require the ship to be at sea and the working conditions to be in accordance with the relevant test schedule, covering all the characteristic loads of a tested propulsion system [17-19]. A very important issue during the tests at sea is the measurement and recording of usable torque, which clearly defines the load of the tested propulsion system and the measurement and recording of fuel consumption. Since not all marine propulsion systems are equipped with measuring systems for measuring the torque and fuel consumption, some may require measurement and determination using available methods and measuring instruments [16, 23].

Examples of characteristics of a naval gas turbine, recorded during energy tests of naval gas turbines operated in the Polish Navy, are presented on figures 7-15. Designation of individual parameters are in accordance with the engine operating parameters contained in table 3, as presented in the article Operational diagnostics synthesis of the naval gas turbines operated by the Polish Navy. 


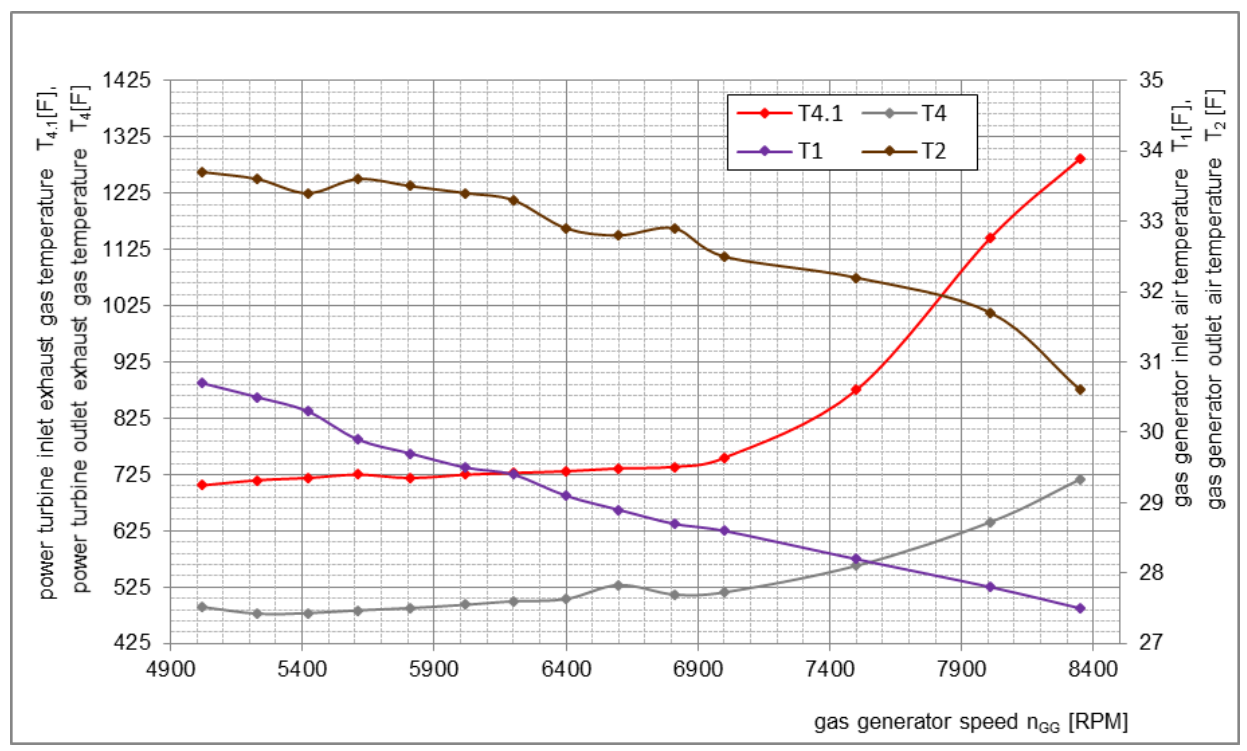

Fig. 7. The course of changes in gas generator inlet air temperature $T_{1}$ and outlet air temperature $T_{2}$ and power turbine inlet exhaust gas temperature $T_{4.1}$ and outlet exhaust gas temperature $T_{4}$, for fixed operating conditions of an LM 2500 engine, depending on the gas generator speed $n_{\mathrm{GG}}$ [own study]

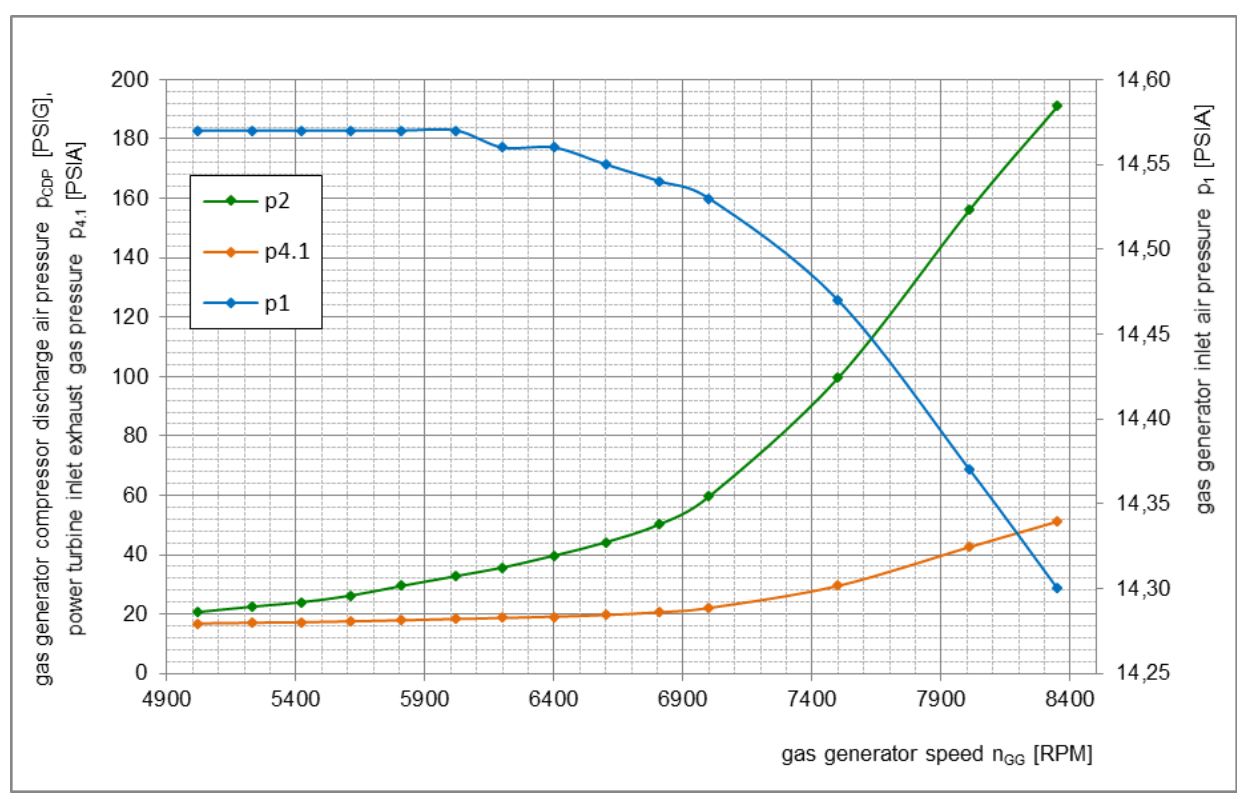

Fig. 8. The course of changes in gas generator inlet air pressure $p_{1}$ and gas generator compressor discharge air pressure $p_{\mathrm{CDP}}$ and power turbine inlet exhaust gas pressure $p_{4.1}$, for fixed operating conditions of an LM 2500 engine, depending on the gas generator speed $n_{\mathrm{GG}}$ [own study] 


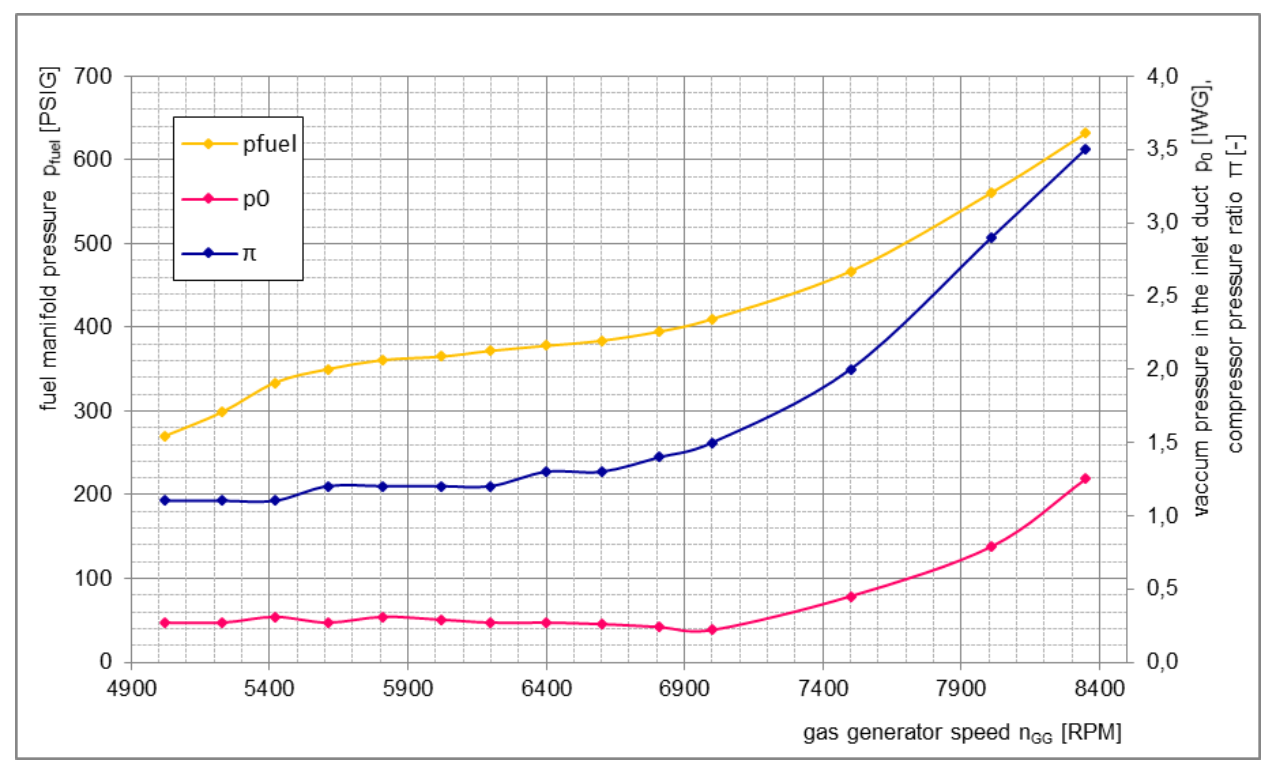

Fig. 9. The course of changes in vaccum pressure in the inlet duct $p_{0}$ and compressor pressure ratio $\pi$ and fuel manifold pressure $p_{\text {fuel, }}$ for fixed operating conditions of an LM 2500 engine, depending on the gas generator speed $n_{\mathrm{GG}}$ [own study]

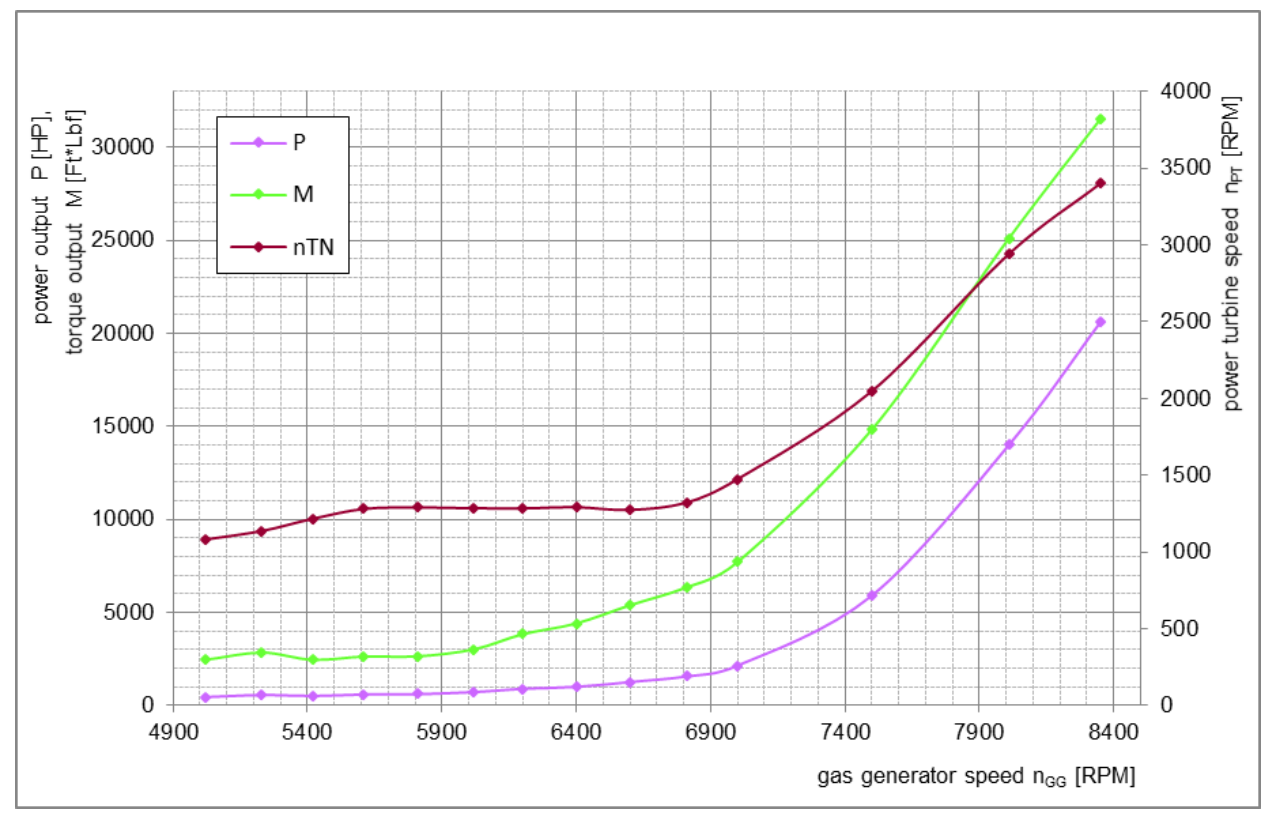

Fig. 10. The course of changes in power output $P$ and torque output $M$ and power turbine speed $n_{\mathrm{PT}}$, for fixed operating conditions of an LM 2500 engine, depending on the gas generator speed $n_{\mathrm{GG}}$ [own study] 


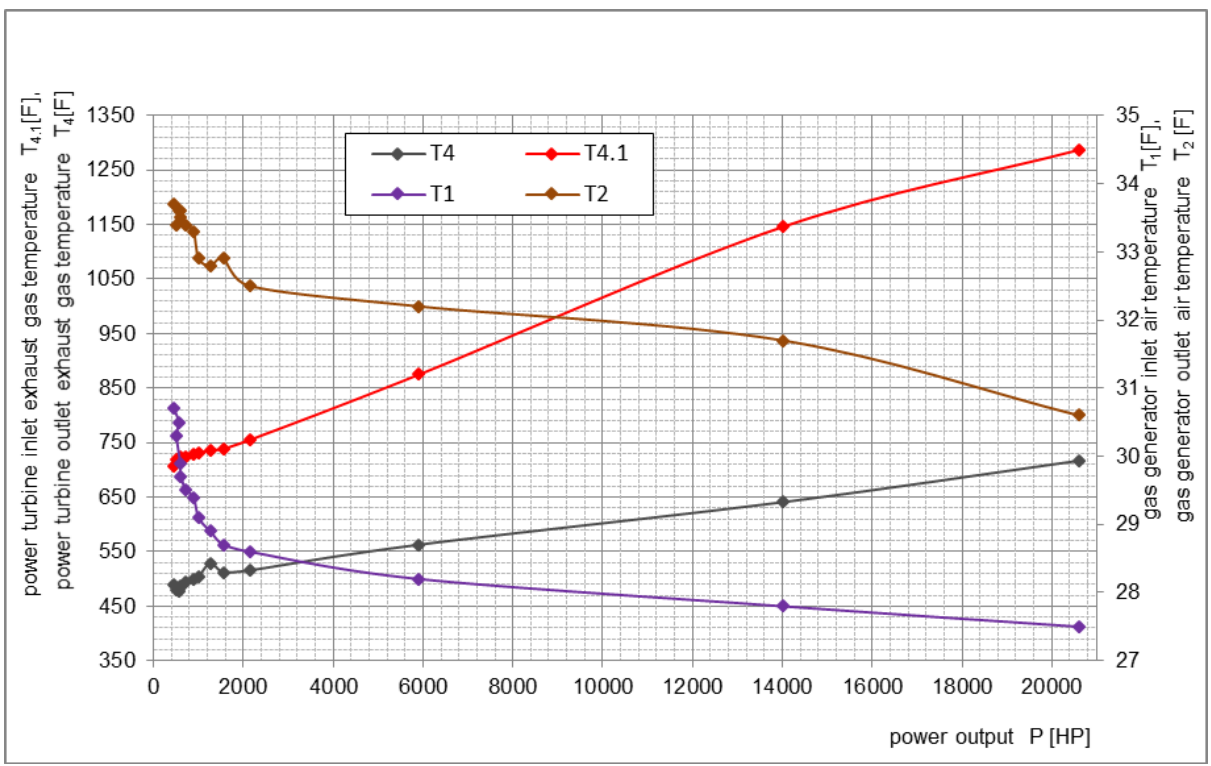

Fig. 11. The course of changes in gas generator inlet air temperature $T_{1}$ and outlet air temperature $T_{2}$ and power turbine inlet exhaust gas temperature $T_{4.1}$ and outlet exhaust gas temperature $T_{4}$, for fixed operating conditions of an LM 2500 engine, depending on the power output $P$ [own study]

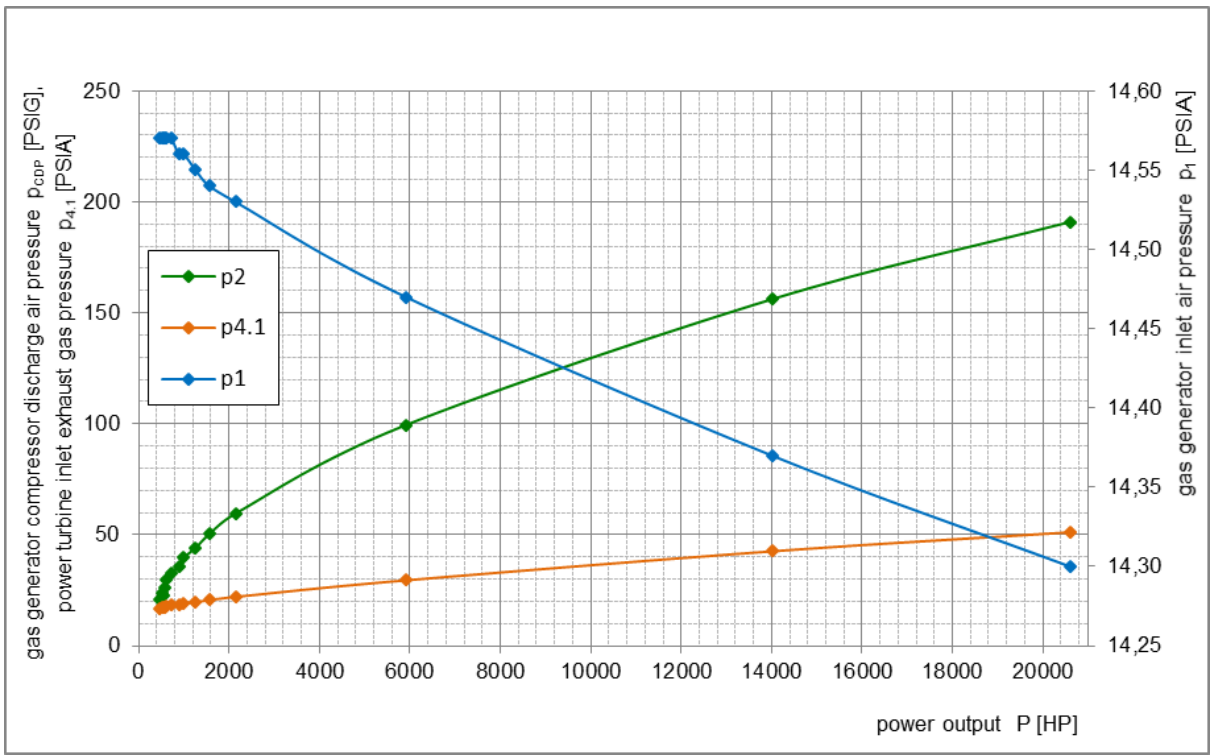

Fig. 12. The course of changes in gas generator inlet air pressure $p_{1}$ and gas generator compressor discharge air pressure $p_{\mathrm{CDP}}$ and power turbine inlet exhaust gas pressure $p_{4.1}$, for fixed operating conditions of an LM 2500 engine, depending on the power output $P$ [own study] 


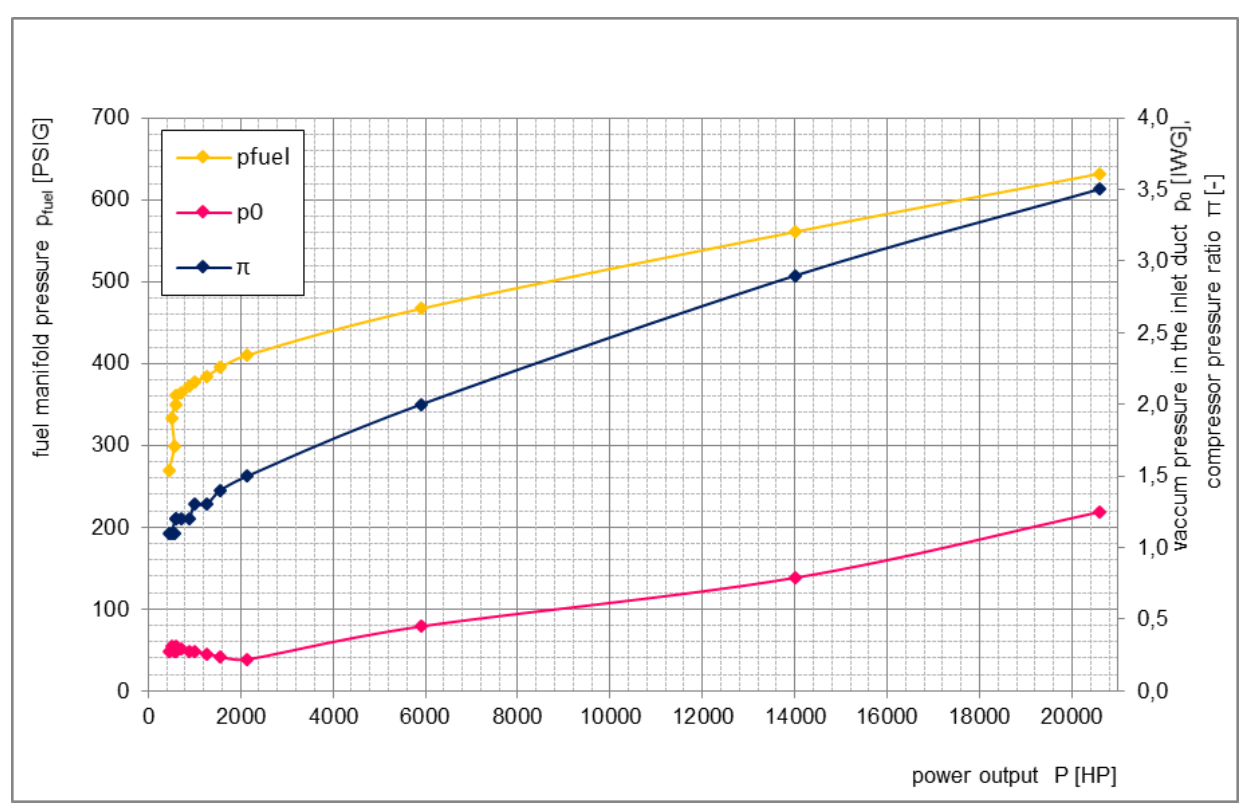

Fig. 13. The course of changes in vaccum pressure in the inlet duct $p_{0}$ and compressor pressure ratio $\pi$ and fuel manifold pressure $p$ fuel, for fixed operating conditions of an LM 2500 engine, depending on the power output $P$ [own study]

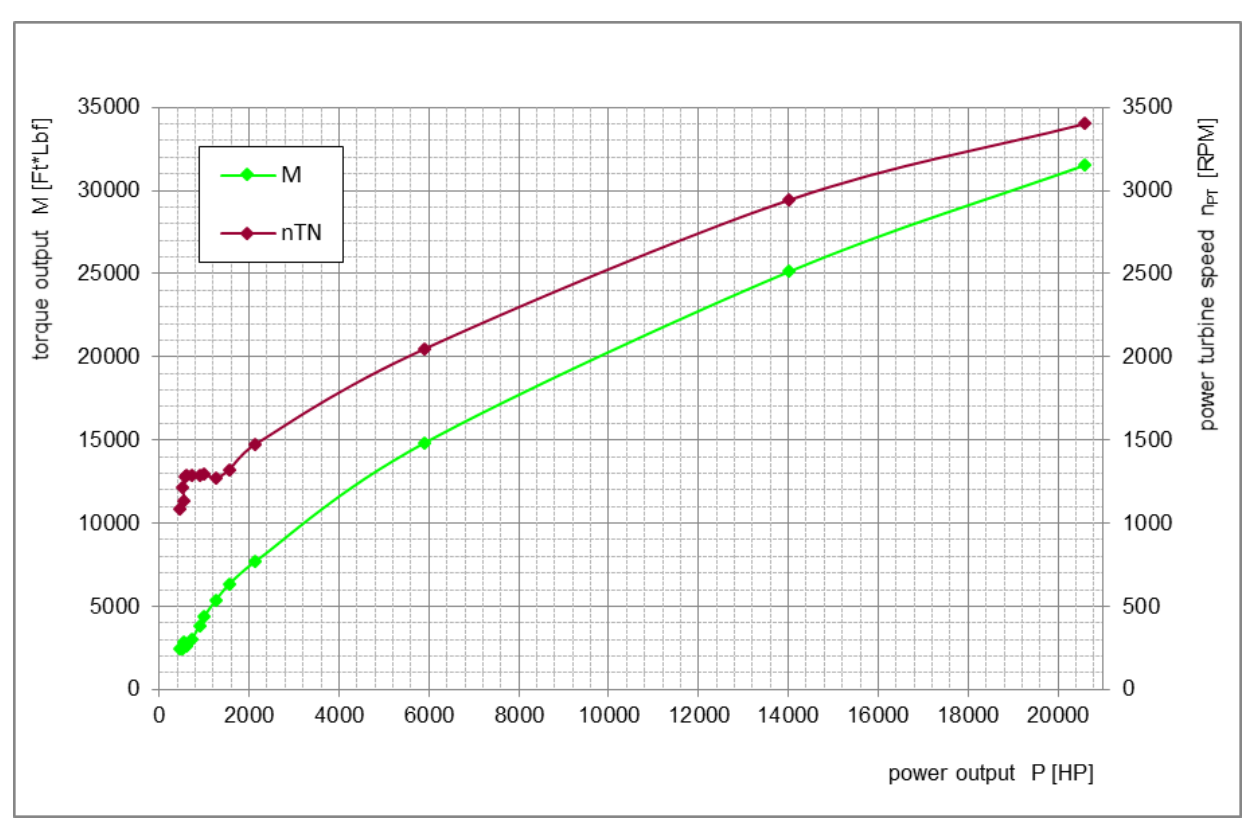

Fig. 14. The course of changes in power output $P$ and torque output $M$ and power turbine speed $n_{\mathrm{PT}}$, for fixed operating conditions of an LM 2500 engine, depending on the power output $P$ [own study] 


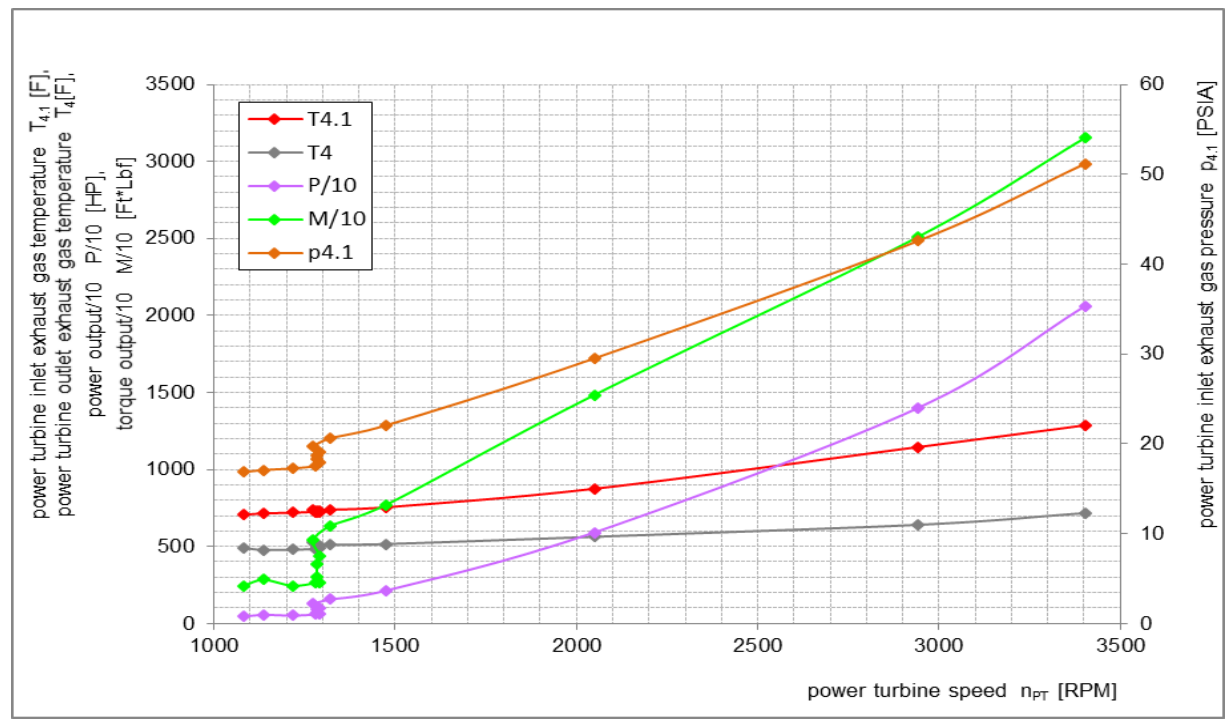

Fig. 15. The course of changes in power turbine inlet exhaust gas temperature $T_{4.1}$ and outlet exhaust gas temperature $T_{4}$ and power output $P$ and torque output $M$ and power turbine inlet exhaust gas pressure $p_{4.1}$, for fixed operating conditions of an LM 2500 engine, depending on the power turbine speed $n_{\mathrm{PT}}$ [own study]

The process of exploitation of naval gas turbines also requires the knowledge of their characteristics in the process of acceleration and deceleration of the engine. These characteristics represent the change dynamics of various engine parameters at the time of increasing or decreasing a load. On this basis, it is possible to evaluate the prevalence of unstable ranges of engine operation, which may lead to the pumping $[9,10,14]$. The course of changes in an LM 2500 engine selected operating parameters during acceleration and deceleration is presented in figures 16-17. Designation of individual parameters is in accordance with the engine operating parameters contained in table 3, as presented in the article Operational diagnostics synthesis of the naval gas turbines operated by the Polish Navy.

Based on the measurement results, recorded during engine operation at loads and the developed characteristics, also performed are $[8,11,12,15]$ :

- verification of the vessel control and measurement system indications, by comparing the measured parameter values with the control parameters contained in the operational documentation of the test engine;

- assessment of the correctness of engine adjustment, including the assessment of the correct operation of fuel equipment in established conditions (e.g.: based on the temperature of the exhaust area past the gas generator — fig. 18);

- observe the engine condition based on diagnostic symptoms referred to in particular diagnostic methods, including the intensity of contamination of the flow 
duct of the engine (e.g.: based on changes in rotary speed-slip for rotor assemblies in two-rotor gas generators $\left(\Delta n_{\mathrm{LP}}\right)$, changes in gas generator compressor discharge air pressure $\left(\Delta p_{\mathrm{CDP}}\right)$, power turbine inlet exhaust gas temperature $\left(\Delta T_{4.1}\right)$ or power turbine inlet exhaust gas pressure $\left(\Delta p_{4.1}\right)$ - figure 19.

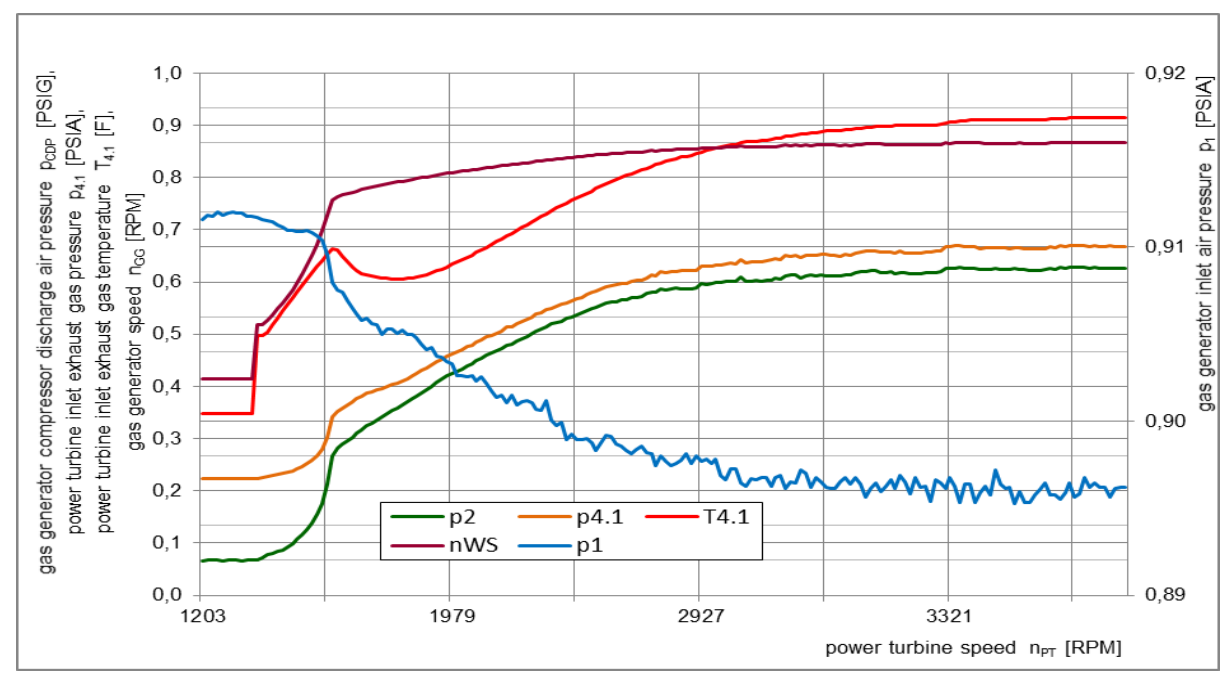

Fig. 16. Changes of LM 2500 engine operating parameters depending on the power turbine speed $n_{\text {PT }}$ during acceleration [own study]

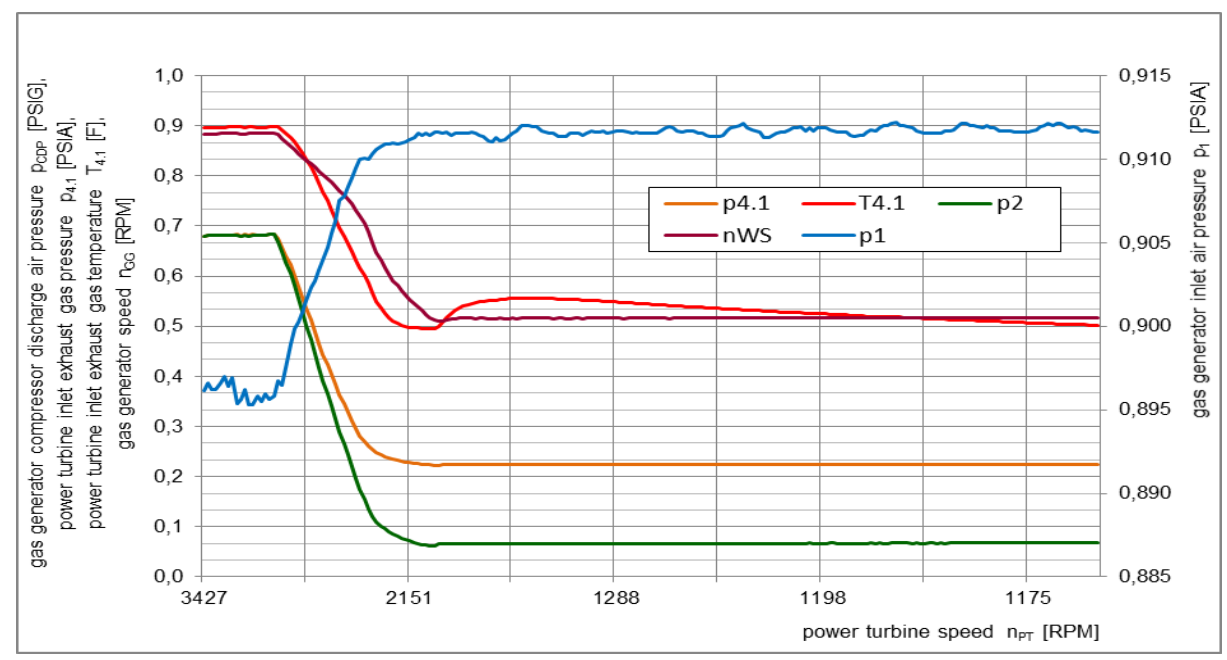

Fig. 17. Changes of LM 2500 engine operating parameters depending on the power turbine speed $n_{\text {PT }}$ during deceleration [own study] 


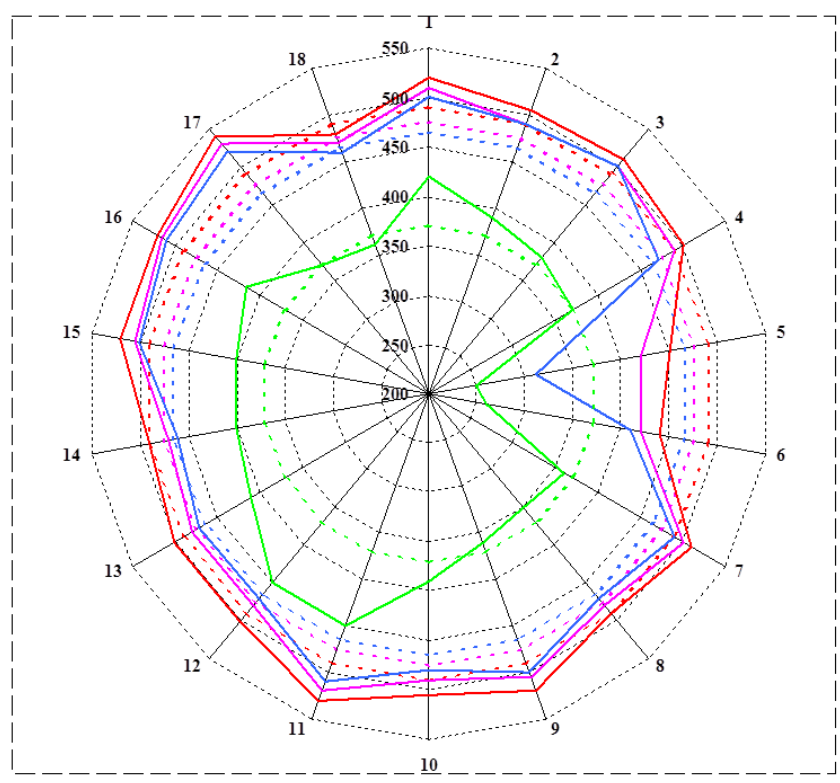

Fig. 18. DR 76 engine thermal field of power turbine inlet exhaust gas temperature:

- idle mode (average temp. $370^{\circ} \mathrm{C}$ ); - 0,2 $\mathrm{P}_{\text {nom }}$ (average temp. $465^{\circ} \mathrm{C}$ ); $-0,3 \mathrm{P}_{\text {nom }}$ (average temp. $475^{\circ} \mathrm{C}$ ); - 0,4 $\mathrm{P}_{\text {nom }}$ (average temp. $490^{\circ} \mathrm{C}$ ); 1-18 - thermocouple numbers; 200-550 -

exhaust temperature range in ${ }^{\circ} \mathrm{C}$; solid lines - connection of indications of exhaust gas temperature of respective thermocouples; dashed lines - the average exhaust temperature values on the engine room TSTP indicator [own study]

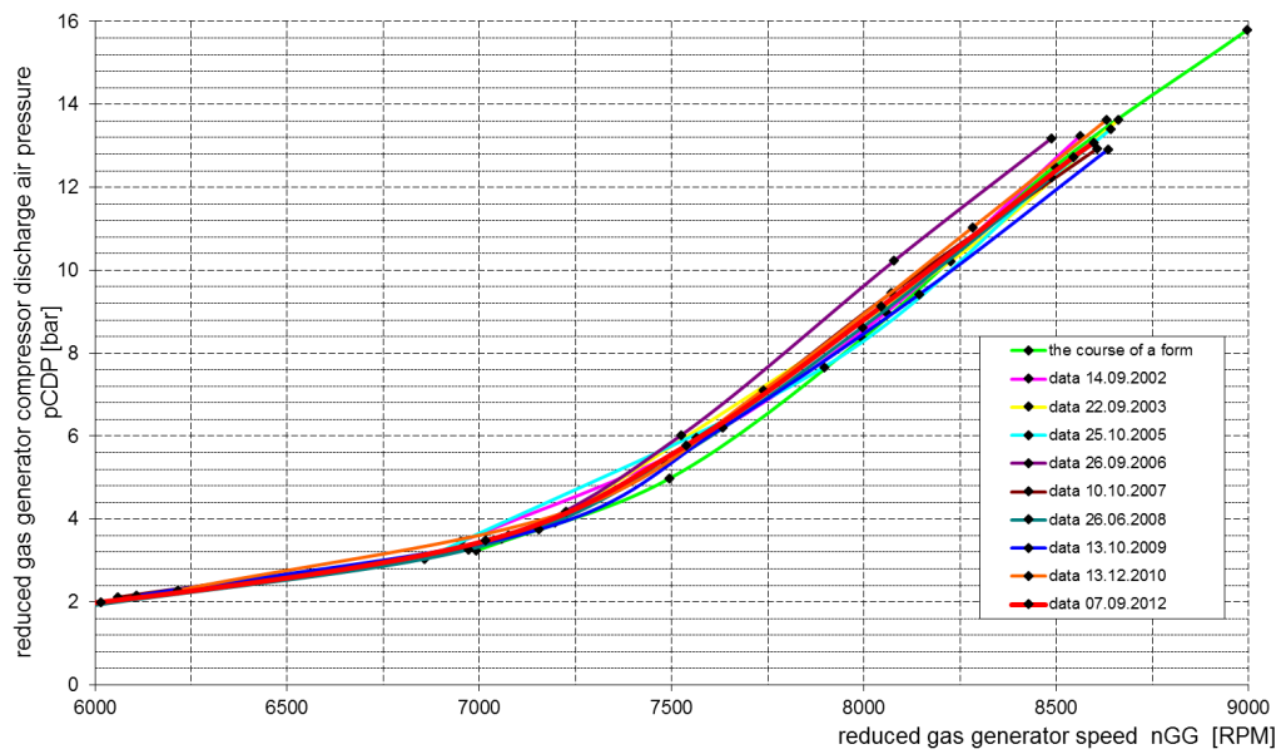

Fig. 19. Changes in deviation between the actual gas generator compressor discharge air pressure $p_{\mathrm{CDP}}$ and the form pressure [own study] 


\section{CONCLUSIONS}

The results of systematic energy research in the context of exploitation diagnostics of naval gas turbines operated in the Polish Navy allowed a change of strategy of utilizing the engines - from utilization by the amount of work, to a strategy based on technical conditions. Observing the change trends of the course of characteristics of engines tested and selected diagnostic symptoms allows to obtain information that could be used in making decisions regarding the operational readiness of ships. This information is also used for engine adjustment, planning of its service, as well as component replacement and repair of engines. This is particularly important at a time when the exploitation of the engines, including their repairs, has limited allocated funds. The experience gained from the exploitation diagnostics of engines may also be applied in the processes of modernization and construction of new engines.

Exploitation of engines by the Polish Navy based on their condition allowed in recent years for the extension of their usability periods between overhauls, and thus for maintaining the combat readiness of ships. Currently, based on this strategy and with success, LM 2500 engines are exploited on ships, which have now been in service for more than 38 years.

The functional characteristics co-relations of the tested engines, developed based on the results of energy research measurements, allow for an analytical determination of the parameters of their work, for any possible environmental parameters. These relations allow for approximate determination of the operating parameters of an engine, but still with sufficient precision for engineering applications, for the needs of further research (modeling) of this type of engines.

Knowledge and experience resultant from diagnostic tests is also used in education and training of personnel responsible for the operation of this type of engine, implemented at the Mechanical-Electrical Faculty of the Polish Naval Academy in Gdynia. This is especially important, because improper exploitation often leads to serious damage, affecting the combat readiness of a ship, and thus also generating large and unexpected costs of operation. 


\section{REFERENCES}

[1] Cempel C., Tomaszewski F., Diagnostyka maszyn, Międzyresortowe Centrum Naukowe Eksploatacji Majątku Trwałego, Radom 1992 [Diagnostics of machines — available in Polish].

[2] Charchalis A., Diagnozowanie okrętowych silników turbinowych, AMW, Gdynia 1991 [Diagnosis of naval gas turbines - available in Polish].

[3] Charchalis A., Korczewski Z., Badania diagnostyczne okrętowych turbinowych silników spalinowych na podstawie analizy zmian parametrów termogazodynamicznych, XIV Międzynarodowe Sympozjum Siłowni Okrętowych, Szczecin 1992, pp. 63-71 [Diagnostic tests of naval gas turbines based on analysis of changes in thermogasic parameters - available in Polish].

[4] Charchalis A., Korczewski Z., Metody diagnozowania okrętowych turbinowych silników spalinowych, 'Przegląd Mechaniczny', No. 3-4, 1997, pp. 45-57 [Methods of diagnosis of naval gas turbines - available in Polish].

[5] Charchalis A., Pojawa B., Ocena stanu technicznego okrętowego turbinowego silnika spalinowego na podstawie badań momentu obrotowego przy rozruchu, XXVIII Ogólnopolskie Sympozjum 'Diagnostyka maszyn', Węgierska Górka 2001, pp. 133-140 [Assessment of the technical state of the naval gas turbine based on torque tests at start-up - available in Polish].

[6] Charchalis A., Wirkowski P., Badania eksploatacyjne okrętowych turbinowych silników spalinowych LM 2500, 'Diagnostyka', 2004, Vol. 30/1, pp. 106-110 [Exploitation's researches of marine gasturbines LM 2500 — available in Polish].

[7] Charchalis A., Wróblewski K., Włoch J., Diagnostyka okrętowego turbinowego silnika spalinowego na podstawie eksploatacyjnych parametrów rozruchu, XIV Międzynarodowe Sympozjum Siłowni Okrętowych, Szczecin 1992, pp. 73-85 [Diagnostics of the naval gas turbine based on operational starting parameters - available in Polish].

[8] Diagnostyka okrętowych turbinowych silników spalinowych, AMW, Gdynia 1996, targeted project No. 148-23/C-SO/93 [Diagnostics of naval gas turbines - available in Polish].

[9] Korczewski Z., Identyfikacja procesów gazodynamicznych w zespole sprężarkowym okrętowego turbinowego silnika spalinowego dla potrzeb diagnostyki, 'Zeszyty Naukowe AMW', 1999, No. 138A [Identification of gas-dynamic processes in the compressor assembly of a naval gas turbine for diagnostic purposes - available in Polish].

[10] Korczewski Z., Simulation model of the compressors configuration of naval gas turbine for diagnostic purposes, 'Marine Technology Transactions. Technika Morska', 1997, Vol. 8.

[11] Metodyka badań okrętowych turbinowych silników spalinowych typu DR76 i DR77 użytkowanych w MW RP, praca zbiorowa, AMW, Gdynia 2006 [Methodology of research of naval gas turbines DR76 and DR77 used in Polish Navy, group work — available in Polish].

[12] Metodyka badań okrętowych turbinowych silników spalinowych typu LM 2500 użytkowanych w MW RP, praca zbiorowa, AMW, Gdynia 2006 [Methodology of research of naval gas turbines LM 2500 used in Polish Navy, group work — available in Polish].

[13] Moczulski W., Diagnostyka techniczna. Metody pozyskiwania wiedzy, Publ. Silesian University of Technology, Gliwice 2002 [Technical diagnostics. Knowledge acquisition methods - available in Polish]. 
[14] Ocena stanu technicznego okrętowych turbinowych silników spalinowych w oparciu o badania ich cech dynamicznych, AMW, Gdynia 1995-1998, research project No. 9T12D00811 [Assessment of the technical state of naval gas turbines based on their dynamic characteristics — available in Polish].

[15] Opracowanie systemu diagnostycznego okrętowych turbinowych silników spalinowych fregat wdrażanych w Marynarce Wojennej RP, AMW, Gdynia 1995-1998, research project No. 0 T00A 06219 [Development of a diagnostic system for naval gas turbines of frigates deployed in the Polish Navy — available in Polish].

[16] Pojawa B., Borsuk K., Wyznaczenie charakterystyki współpracy okrętowego turbinowego silnika spalinowego z odbiornikiem energii z wykorzystaniem techniki planowania eksperymentu, 'Zeszyty Naukowe AMW', 2012, No. 2, pp. 103-122 [Determining co-operation characteristics of marine gas turbine engine with power receiver using methodology planning experiment — available in Polish].

[17] Pojawa B., Characteristics Determination of LM-2500 Naval Gas Turbine in Aspect of Energy Modeling and Simulations, 'Solid State Phenomena', 2015, Vol. 236, pp. 169-179.

[18] Pojawa B., Charakterystyki okrętowych turbinowych silników spalinowych w stanach pracy ustalonej, 'Zeszyty Naukowe AMW', 2011, No. 4, pp. 83-102 [The characteristic of marine gas turbines in stationary mode - available in Polish].

[19] Pojawa B., Hołdowska M., Determination of operating characteristics of naval gas turbines LM 2500, 'Journal of KONES', 2011, Vol. 18/4, pp. 369-376.

[20] Pojawa B., Metoda diagnozowania układu rozruchowego okrętowego turbinowego silnika spalinowego, PhD thesis, AMW, Gdynia 2003 [Method of diagnosis of the start-up system of a naval gas turbine - available in Polish].

[21] Pojawa B., Studying the effects of changes in ambient condition parameters on the torque characteristics of a naval gas turbine, 'Combustion Engines', 2015, No 162(3), pp. 105-1020.

[22] Pojawa B., The energetic diagnostics of naval propulsion system with naval gas turbine, 'Diagnostyka', 2009, Vol. 50/1, pp. 55-58.

[23] Pojawa B., The Investigation of Turbine Engine in Aspect of Output Torque Control, 'Solid State Phenomena', 2011, Vol. 180, pp. 339-348.

[24] Sprawozdania z badań diagnostycznych turbinowych silników spalinowych eksploatowanych na okrętach MW RP, AMW, Gdynia 1985-2016, research and service [Reports on diagnostic tests of naval gas turbines operating in Polish Navy — available in Polish].

[25] Włoch J., Diagnozowanie okrętowych turbinowych silników spalinowych na podstawie wielkości charakteryzujacych przebieg rozruchu i zatrzymania, PhD thesis, AMW, Gdynia 1994 [Diagnosing naval gas turbines on the basis of parameters characterizing the start-up and stop process available in Polish].

[26] Żółtowski B., Podstawy diagnostyki maszyn, Publ. University of Technology and Agriculture, Bydgoszcz 1996 [Fundamentals of machine diagnostics — available in Polish]. 


\section{WYNIKI BADAŃ ENERGETYCZNYCH OKRĘTOWYCH TURBINOWYCH SILNIKÓW SPALINOWYCH EKSPLOATOWANYCH W MARYNARCE WOJENNEJ RP}

\section{STRESZCZENIE}

Artykuł jest kontynuacją tematyki przedstawionej w artykule Operational diagnostics synthesis of the naval gas turbines operated by the Polish Navy opublikowanym w SJ of PNA No. 1/2017. Zaprezentowano w nim przykłady wyników badań energetycznych wykonywanych przez Akademię Marynarki Wojennej w latach 1985-2016 na potrzeby diagnostyki eksploatacyjnej tego typu silników użytkowanych w MW RP. Badaniami prowadzonymi od 1985 roku objęte były cztery typy okrętowych turbinowych silników spalinowych (DE 59, DR 76, DR 77 i LM 2500), o łącznej liczbie 24 sztuk. Obecnie w eksploatacji znajdują się cztery silniki typu LM 2500. W najbliższej perspektywie do eksploatacji wejdzie kolejny silnik typu LM 2500 wraz z okrętem patrolowym projektu 661M. W ramach badań energetycznych nadzorem eksploatacyjnym objęty jest proces rozruchu silników, ich praca na biegu jałowym oraz w całym zakresie zmienności obciążeń, a także proces zatrzymania silników. W artykule przedstawiono przykłady charakterystyk właściwych dla powyższych procesów wyznaczonych na podstawie wyników badań poszczególnych typów silników. Bieżące badania umożliwiają prowadzenie strategii eksploatacji okrętowych turbinowych silników spalinowych eksploatowanych w MW RP według stanu technicznego.

\section{Słowa kluczowe:}

diagnostyka techniczna, okrętowy turbinowy silnik spalinowy, stan techniczny, silnik LM 2500.

Article history

Received: $\quad 04.12 .2017$

Reviewed: 22.12.2017

Revised: $\quad 02.02 .2018$

Accepted: $\quad 05.02 .2018$ 